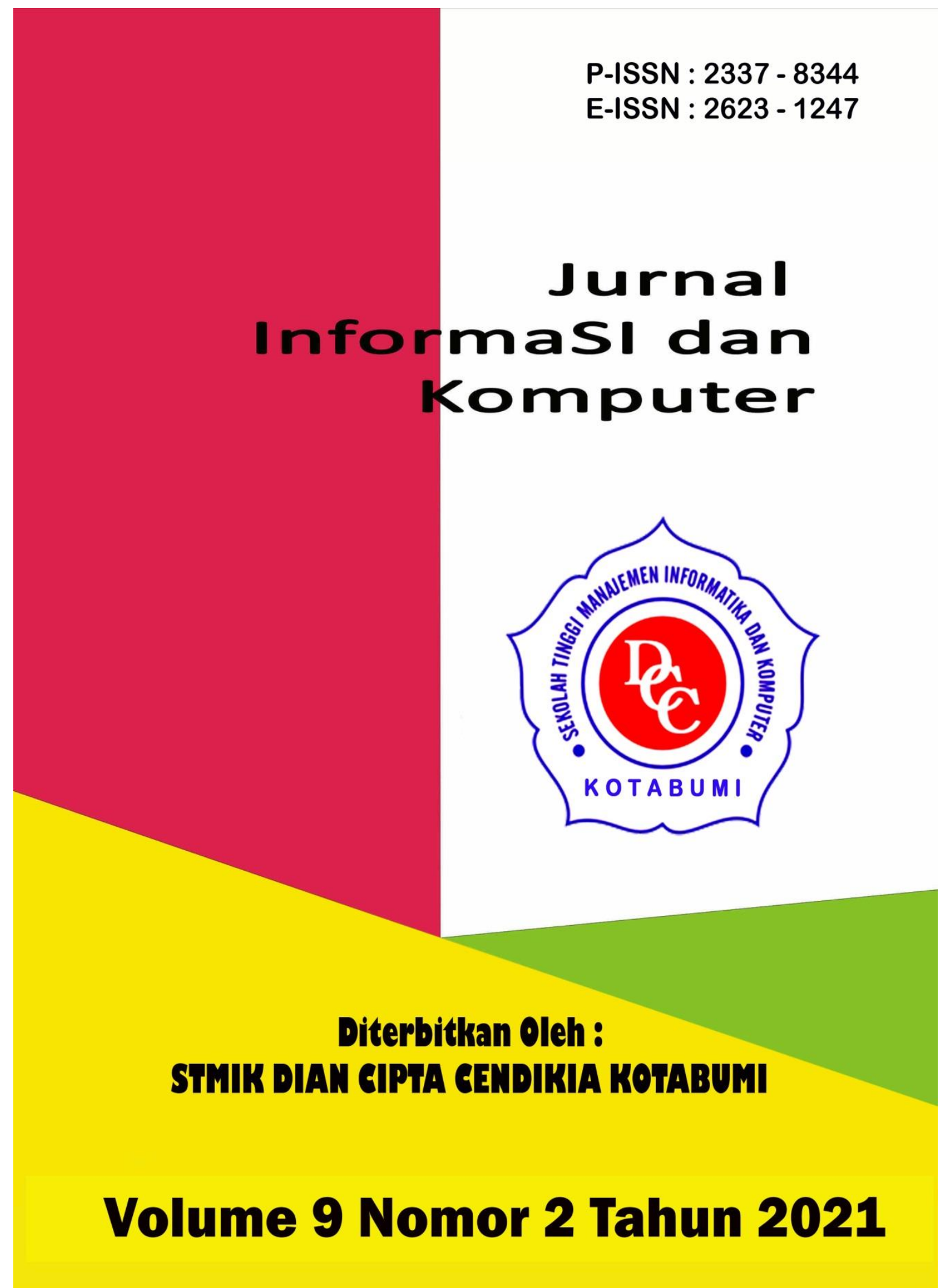




\section{Penerbit}

\section{Lembaga Penelitian STMIK Dian Cipta Cendikia Kotabumi}

Hak atas naskahh/tulisan tetap berada pada penulis, isi diluar tangung jawab penerbit dan Dewan Penyunting 


\section{PENGANTAR REDAKSI}

Puji syukur dipanjatkan kehadirat Tuhan Yang Maha Esa, atas karunia dan limpahan rahmatNYA jualah Jurnal Informasi dan komputer (JIK) STMIK Dian Cipta Cendikia Kotabumi ini dapat terwujud.Jurnal Informasi dan Komputer (JIK) yang terbit dua (2) kali dalam setahun ini merupakan suatu wadah untuk penyebar luasan hasil-hasil penelitian, studi pustaka, karya ilmiah yang berkaitan dengan Informasi dan Komputer khususnya bagi dosen-dosen STMIK Dian Cipta Cendikia Kotabumi serta umumnya para cendikiawan, praktisi, peneliti ilmu Informatika dan Komputer.

Harapan, dengan diterbitkannya Jurnal Informasi dan Komputer (JIK) ini sebagai salah satu bentuk sumbangan pemikiran dalam pengembangan ilmu informatika dan komputer yang berkaitan dengan kajian-kajian di bidang tekhnologi Informatik, Komunikasi Data dan Jaringan Komputer, perancangan dan Rekayasa Perangkat Lunak, serta ilmu-ilmu yang terkait dengan bidang Informasi dan Komputer lainnya.

Berkenaan dengan harapan tersebut, kepada para peneliti, dosen dan praktisi yang memiliki hasil-hasil penelitian, kajian pustaka, karya ilmiah dalam bidang tersebut diatas, dengan bangga redaksi Jurnal Informasi dan Komputer (JIK) menerima naskah ringkasan untuk dimuat pada jurnal Informasi dan Komputer (JIK) STMIK Dian Cipta Cendikia Kotabumi dengan berpedoman pada penulisan naskah jurnal sebagaimana dilampirkan pada halaman belakang (Bagian kulit dalam) buku jurnal ini.

Mutu dari suatu jurnal ilmiah tidak hanya ditentukan oleh para pengelolanya saja, tetapi para penulis dan pembaca jualah yang mempunyai peranan besar dalam meningkatkan mutu jurnal Informatika dan Komputer ini. Merujuk pada realita ini kamu sangat mengharapkan peran aktif dari peneliti untuk bersama-sama menjaga dan memelihara keberlangsungan dari jurnal Informasi dan Komputer STMIK Dian Cipta Cendikia Kotabumi ini. Yang juga tidak kalah pentingnya dari partisipasi tersebut diatas, adalah saran dan kritik yang membangun dari pembaca yang budiman agar kiranya dapat disampaikan langsung kepada redaksi JIK. Saran dan kritik yang membangun akan dijadikan masukan dan pertimbangan yang sangat berarti guna peningkatan mutu dan kualitas Jurnal Informasi dan Komputer STMIK Dian Cipta Cendikia Kotabumi.

Tak lupa diucapkan terima kasih yang tak terhingga atas perhatian dan kerjasama dari semua pihak yang tak dapat disebutkan satu persatu hingga dapat diterbitkan nya Jurnal Informasi dan Komputer (JIK) STMIK Dian Cipta Cendikia Kotabumi. Semoga apa yang telah diperbuat untuk kebaikan akan menjadi amal ibadah, amin.

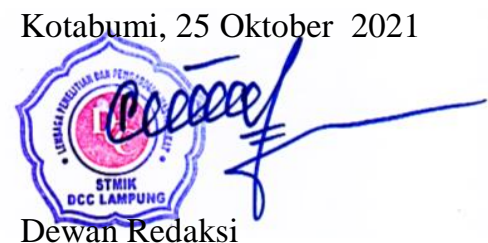




\section{JURNAL INFORMASI DAN KOMPUTER}

Volume 9 Nomor 2 Oktober 2021

Jurnal Informasi dan Komputer merupakan Sarana informasi ilmu pengetahuan, Tekhnologi dan Komunikasi yang berupa hasil penelitian, tulisan ilmiah, Ataupun studi pustaka. Jurnal ini terbit dua kali setahun pada bulan April dan Oktober. Berisi hasil penelitian ilmiah di bidang informatika yang bertujuan untuk menghubungkan adanya kesenjangan antar kemajuan teknologi dan hasil penelitian. Jurnal ini di terbitkan pertama kali pada tahun 2013.

Penanggung Jawab:

Ketua STMIK Dian Cipta Cendikia Kotabumi

\section{Pembina:}

Ketua STMIK Dian Cipta Cendikia Kotabumi Ketua Lembaga Penelitian STMIK Dian Cipta Cendikia Kotabumi

\section{Pimpinan Redaksi}

Dwi Marisa Efendi,.S.Kom.,M.Ti

\section{Redaksi pelaksana}

Rustam,.S.Kom,.M.Ti (STMIK Dian Cipta Cendikia Kotabumi)

Nurmayanti M.Kom (STMIK Dian Cipta Cendikia Kotabumi)

Sukatmi,.S.Kom., M.Kom (AMIK DCC Bandar Lampung)

Sampurna Dadi Riskiono,M.Kom (Universitas Teknokrat Indonesia)

Ifo Wahyu Pratama,S.Kom.,M.Ti(AMIK MASTER Lampung)

\section{Mitra Bestari}

Dr. RZ. ABDUL AZIZ, ST., MT (Institut Informatika dan Bisnis Darmajaya)

Dr. Dadang Sudrajat, S.Si, M.Kom (STMIK IKMI Cirebon)

Dr. Septafiansyah Dwi Putra, S.T., M.T (Politeknik Negeri Lampung)

Dr. Evi Grativiani, S.E., M.S.I (Universitas Sebelas Maret)

Rohmat Indra Borman ( Universitas Teknokrat Indonesia )

Ferry Wongso, S.KOm., M.Kom ( STMIK Darma Pala Riau)

Ferly Ardhy, S.Kom., M.Ti ( Universitas Aisyah Pringsewu )

Firmansyah, S.E., M.Si (STMIK Darma Pala Riau)
Amarudin (Universitas Teknokrat Indonesia)

Didi Susianto, S.T., M.Kom (AMIK Dian Cipta Cendika Bandar Lampung)

Alhibarsyah, St., M.Kom (STMIK Tunas

Bangsa Bandar Lampung)

Kemal Farouq Mauladi, S.Kom .M.Kom (Universitas Islam Lamongan)

Rima Mawarni, M.Kom ( STMIK Dian Cipta Cendikia Kotabumi)

Wira Jaya Hartono, S.Pd., M.Pd ( STMIK Darma Pala Riau)

Penerbit : STMIK Dian Cipta Cendikia Kotabumi Bekerja Sama Dengan LPPM STMIK Dian Cipta Cendikia Kotabumi.

\section{Alamat Redaksi/Penerbit:}

Jl. Negara No. 3 Candimas Kotabumi Lampung Utara

No Telpon/Fax 072423003

Email : 1ppm-stmik@dcc.ac.id 


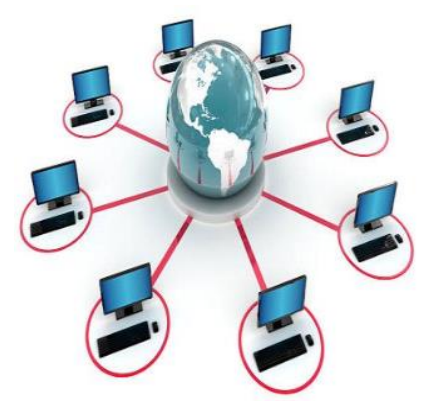

\section{JURNAL INFORMASI DAN KOMPUTER VOL. 9 NO. 2 THN. 2021}

\section{DAFTAR ISI}

Halaman

Sistem Informasi Akuntansi Persedian Barang Berbasis Web Pada Lembaga

Permasyarakatan Kelas II A Banceuy Bandung : "Kelompok Tani Desa Banjar Kertarahayu" Teuku Rian Hardiyansyah, Fatia Salsa Azzahra (Politeknik Piksi Ganesha Bandung ${ }^{1,2}$ ).

Penerapan Finite State Automata Pada Vending Machine Penjual Obat Non Resep

Dokter Dan Keperluan Medis

Eko Supriyanto $^{1}$, Angga Ardiansyah ${ }^{2}$, Frieyadie $^{3}$, Sri Rahayu ${ }^{4}$, Windu Gata ${ }^{5}$

(Universitas Nusa Mandiri ${ }^{12}$ )

Sistem Pendukung Keputusan Untuk Menentukan Kelayakan Pengajuan Sertifikasi Guru Dengan Metode Simple Additive Weighting (Studi Kasus : Ma Al Muhajirin Janti Jogoroto Jombang)

Budiman, umam baharudin, winarti

(Universitas Darul 'Ulum Jombang)

Perancangan Infrastruktur Domain Name Server Lokal Menggunakan Ubuntu Server 16.04

Pada PT. Xyz

Zaenal Mutaqin Subekti, Hendra Setiawan, Satria, Widia Murni Wijaya,

Aliy Hafiz, Warsudi

(STMIK Bani Saleh, Universitas Negeri Yogyakarta, AMIK Dian Cipta Cendikia,

STMIK MIC CIkarang)

Perancangan Sistem Informasi Idea Proposal (Ip) Berbasis Web Pada Pt. Paxel Algorita Unggul

Julian Murhan Sahputra, Indah Purnamasari

(Universitas Nusa Mandiri ${ }^{12}$ )

Sistem Pendukung Keputusan Untuk Menentukan Ekstrakurikuler Atletik

Berdasarkan Bakat Siswa Menggunakan Metode Profile Matching

Agnes Basuki, Petrus Sokibi, Tiara Eka Putri

(Universitas Catur Insan Cendekia)

Penerapan Algoritma K-Means Untuk Pengelompokan Usia Calon Penerima Vaksin

Di Kab. Ngawi

Irna Yuniarfi, Saifulloh

(Universitas PGRI Madiun ${ }^{12}$ )

System Penilaian Seleksi Calon Karyawan Baru Menggunakan Metode Simple Additive Weighting (SAW) Di PT.TNA

Anik Sri Wahyuningsih, Yudhi Firmansyah

STMIK Dian Cipta Cendikia Kotabumi 
(Universitas Panca Sakti Bekasi ) $63-74$

Perancangan Sistem Informasi Pembayaran SPP Menggunakan Framework Laravel Ichwan Habib Moudi

(Universitas Panca Sakti Bekasi)

Implementasi Algoritma K-Means Dan Algoritma Apriori Optimasi Kinerja Ecu

(Study Kasus Mobil Avanza Dan Xenia)

Sigit Mintoro' Asep Afandi

(STMIK Dian Cipta Cendikia Kotabumi)

Sistem Pakar Penyakit Buah Kakao Untuk Peningkatan Hasil Panen Kakao Menggunakan

Metode Case Base Reasoning (CBR) Berbasis Web Mobile

Aliy hafiz, Verawati

(AMIK Dian Cipta Cendikia,Bandar Lampung)

Penerapan Metode Rapid Application Develomment (RAD) Dalam Pengembangan

Sistem Pemesanan Menu Berbasis Android

Aris Baihaqi, Tumini

(Fakultas Sains dan Teknologi $1^{1,2}$ )

Rancang Bangun Sistem Informasi Geografis Pariwisata Di Lampung Timur

Sukatmi, Rexa Alfa Rizi

(AMIK DCC Bandar Lampung ${ }^{12}$ )

Implementasi Psak No. 45 Pada Proses Penyusunan Laporan Keuangan Menggunakan

M.S. Excel Dan Aplikasi Accurate Accouting Pada STMIK Bani Saleh

Marhakim, Willy Adam

(STMIK Bani Saleh ${ }^{12}$ )

Sistem Prediksi Harga KOPI LAMBAR ( Lampung Barat) Dengan Metode

Backpropagation, dan Double Exponential ( Studi Kasus BUMDES )

Supriyanto, Dwi marisa Efendi,Rhomadhon

(STMIK Dian Cipta cendikia Kotabumi ${ }^{1-}$ )

Sistem Informasi Pemasaran Produk Umkm Berbasis Web Pada Kecamatan Bumi

Nabung Lampung Tengah

Yuli Syafitri, Agus Prasetyo, Reni Astika

(AMIK Dian Cipta Cendikia Bandar Lampung)

Rancang Bangun Aplikasi Pembelajaran Aksara Lampung Berbasis Android

Ferly Ardhy, Hendra Syahrobi

(Universitas Aisyah Pringewu ${ }^{1,}$ STMIK Dian Cipta Cendikia ${ }^{2}$ )

Sistem Pakar Diagnosa Penyakit Kulit Pada Balita Menggunakan Metode Naïve

Bayes Dan Forward Chaining Studi Kasus Puskesmas Cempaka Sungkai Selatan

Sidik Rahmatullah, Rima Mawarni

(STMIK Dian Cipta Cendikia Kotabumi ${ }^{12}$ )

Rekayasa Perangkat Lunak Perhitungan Harga Pokok Produksi Metode

Full Costing Pada Umkm Mitra Cake Di Bandar Lampung

Pitrawati, Arif Sanjaya

(AMIK Dian Cipta Cendikia, Bandar Lampung)

$154-162$

S T M I D i a C i p t a C e n dikia Kot a bu i 
Rancang Bangun Sistem Ujian Online Menggunakan Algoritma Cosine Similarity Berbasis Web

Haryono, Zaenal Mutaqin Subekti, Widiyawati, Hidayatullah (STMIK Bani Saleh ${ }^{1234}$ )

Model Aplikasi Helpdesk Ticketing System Berbasis Web Menggunakan Metode Rad Indra Permana

Pattern Recognition Tulisan Tangan Huruf Hijaiyah Menggunakan Metode

Convolutional Neural Network $(\mathrm{CNN})$

Mufassiril Abror, Nopiyanto

(Universitas Panca Sakti Bekasi ${ }^{12}$ )

Aplikasi Sistem Informasi Keuangan Berbasis Android Di Perumahan Taman

Karang Bahagia

Melda Ayulestari

(Universitas Panca Sakti Bekasi)

Audit Pelayanan Sistem Rujukan Online Puskesmas Menggunakan Framework COBIT 5.0

Nurmayanti, Merri Parida, Ngajiyanto, Ina Anzalna

(STMIK Dian Cipta Cendikia Kotabumi ${ }^{1234}$ )

Perancangan Sistem Informasi Pengolahan Data Nilai Siswa Berbasis Web

Erin Ermawati, Anik Sri Wahyuningsih

(Fakultas Sain dan Teknologi, Universitas Panca Sakti Bekasi ${ }^{12}$ )

Pengembangan Sistem Pelaporan Data Hasil Inspeksi Barang Berbasis Web

Siska Putriani

(Universitas Pancasakti Bekasi)

Penerapan Extreme Programming Dalam Perancangan Aplikasi Web Food Market

Tumini, Hilman Septiana

(Fakultas Sains dan Teknologi Universitas Panca Sakti Bekasi ${ }^{1,2}$ )

Sistem Pencarian Barang Berbasis Website Menggunakan Php Dan Mysql

Studi Kasus PT. Surya Technology Industri Sulaeman

(Universitas Panca Sakti Bekasi)

Implementasi Metode Prototype Pada Sistem Peminjaman Alat Kerja Berbasis Web

Di PT SK Metalindo

Ali Mulyanto, Arjun Gunawan

(Univeritas Panca Sakti Bekasi)

Aplikasi Tata Cara Wudhu Menggunakan Teknologi Augmented Reality

Sebagai Media Pembelajaran Di TK Al Fatih

Ahmad Yakub, Idarul Fadli

(Universitas Panca Sakti Bekasi ${ }^{12}$ )

Sistem Pakar Diagnosa Penyakit Ayam Petelur Menggunakan Metode Certainty Factor

Berbasis Web Mochammad

$$
\text { STM IK Dian Cipta Cendikia Kotabum i }
$$


Taufiq Hidayat, Ali Mulyanto

(Universitas Panca Sakti Bekasi ${ }^{12}$ )

Penerapan Metode Prototyping Dalam Perhitungan Hasil Produksi Menggunakan

Arduino Uno R3 Dan Php Di PT. Indonesia Epson Industry

Amandha Aulia, Ajar Rohmanu

(Universitas Panca Sakti Bekasi ${ }^{12}$ )

System Pendukung Keputusan Penentuan Guru Teladan Dengan Metode Profile Matching

Hasbulloh, Agmawarnida

(Universitas Panca Sakti Bekasi ${ }^{1,2}$ )

Implementasi Waterfall Method Pada Aplikasi Buku Induk Siswa Berbasis Web

Idam Holid, Yogie Krisnayadi

(Universitas Panca Sakti ${ }^{12}$ )

Pengembangan Text To Speech Media Pembelajaran Untuk Pengenalan

Anggota Tubuh Manusia Kelas V Sekolah Dasar

Juwanda Saputra, Ali Mulianto

(Teknik Infomratika Fakulutas Sains dan Teknologi ${ }^{12}$ )

Perancangan Sistem Peminjaman Barang Berupa Aset Tetap Berbasis Web

Pada Lembaga Permasyarakatan Kelas II A Banceuy Bandung

Guntur Salasa Priambodo, Perwito, Candra Mecca Sufyana

(Politeknik Piksi Ganesha Bandung ${ }^{1,2,3}$ )

Metode Pemilihan Karyawan Terbaik Sebagai Penentu Goodwill Perguruan Tinggi

Dengan Menggunakan Metode Topsis (Studi Kasus Perguruan Tinggi Di Lampung Utara)

Dwi Sartika, Pakarti Riswanto

(STMIK Dian Cipta Cendikia Kotabumi)

Sistem Pendukung Keputusan Pemilihan Merek Smartphone Menggunakan

Metode Analytical Hierarchy Process (AHP)

Ade Kiki Fatmawati, Muhammad Sultan Raflie, Norma Yunita

(Universitas Nusa Mandiri ${ }^{123}$ )

Pattern Recognition Aksara Lampung Menggunakan Algoritma Neural Network

Metode Analytical Hierarchy Process (AHP)

Nopiyanto, Rahmadi

(Universitas Panca Sakti Bekasi) 


\title{
PERANCANGAN INFRASTRUKTUR DOMAIN NAME SERVER LOKAL MENGGUNAKAN UBUNTU SERVER 16.04 PADA PT. XYZ
}

\author{
Zaenal Mutaqin Subekti ${ }^{1}$, Hendra Setiawan ${ }^{2}$, Satria $^{3}$, Widia Murni Wijaya ${ }^{4}$, Aliy Hafiz ${ }^{5}$, Warsudi ${ }^{6}$ \\ STMIK Bani Saleh, ${ }^{4}$ Universitas Negeri Yogyakarta, ${ }^{5}$ AMIK Dian Cipta Cendikia, ${ }^{6}$ STMIK MIC \\ CIkarang \\ Jl. M Hasibuan No. 68 Bekasi \\ E-mail : zms.stmikbanisaleh@gmail.com ${ }^{1}$, hendrasetiawan@stmik banisaleh.ac.id ${ }^{2}$, \\ satria1905@gmail.com ${ }^{3}$,widiamw@uny.ac.id ${ }^{4}$,hafizdahsyat@gmail.com ${ }^{5}$, \\ warsudi.nurhakim27@gmail.com6
}

\begin{abstract}
ABSTRAK
Perangkat komputer sangat dibutuhkan dalam menyelesaikan pekerjaan - pekerjaan pada sebuah perusahaan, untuk memudahkan dalam pengambilan data yang terpusat berbagi sumber daya maka komputer harus terhubung dengan jaringan lokal area network. Menggunakan ip address setiap komputer yang berbeda-beda dapat terhubung ke jaringan lokal area network yang dihubungkan dengan kabel atau perantara wirkabel, dalam memudahkan akses sebuah server dapat menerapkan domain name server sehingga mudah untuk mengingat nama domainnya ketimbang harus mengingat ip address nya. Penelitian ini menggunakan beberapa tahapan metode yaitu dimulai dengan analysis yaitu melakukan Analisa kebutuhan perangkat keras dan perangkat lunak, kedua desain yaitu melakukan rancangangan topologi jaringan, ketiga implementasi yaitu melakukan penerapan konfigurasi pada ubuntu server 16.04 dan keempat testing yaitu melakukan pengujian terhadap hasil implementasi. pada pengujian dilakukan, pengujian koneksi menggunakan ip address dan domain dari pengguna ke server menghasilkan terhubung, serta pengujian query dengan perintah nslookup dari pc user ke server menghasilkan dapat menerjemahkan alamat domain dengan ip address.
\end{abstract}

Kata kunci : domain name server, ubuntu server, nslookup.

\section{ABSTRACTS}

Computer equipment is needed to complete the work in a company, to facilitate the retrieval of centralized data sharing resources, the computer must be connected to a local area network. Using the ip address, each different computer can connect to a local area network that is connected by cable or wireless intermediary, in facilitating access a server can apply a domain name server so that it is easy to remember the domain name instead of having to remember the ip address. This study uses several stages of the method, starting with analysis, namely analyzing hardware and software requirements, the second design is to design a network topology, the third implementation is to implement the configuration on the ubuntu server 16.04 and the fourth is to test the results of the implementation. in the tests carried out, testing the connection using the ip address and domain from the user to the server resulted in being connected, as well as testing the query with the nslookup command from the user's pc to the server resulting in being able to translate the domain address with the ip address.

Keywords: domain name server, ubuntu server, nslookup.

\section{PENDAHULUAN}

Kebutuhan menggunakan perangkat personal komputer sangat diperlukan pada suatu perusahaan untuk menyelesaikan tugas-tugas pekerjaan. Untuk menunjang tugas pekerjaan, perangkat komputer membutuhkan terhubung ke jaringan lokal area network untuk berbagi sumber daya atau resoursce seperti sharing print dan sharing folder [1]. Semua perangkat komputer atau personal computer (PC) terhubung ke server [2] untuk mengakses sumber daya seperti data. Perangkat komputer 
membutuhkan ip address untuk berhubungaan antara pc user 1 , pc user 2, pc user 3 dan server [3], terknologi berkembang dengan memudahkan pengguna dapat mengakses server tanpa harus menggunakan ip address, beberapa kemudahan untuk memanggil komputer dengan cara menggunakan computer name dalam satu jaringan, atau dapat menggunakan nama domain name server (dns) [4][5], sehingga dapat memudahkan tidak harus mengingat ip address[6]. Ubuntu merupakan salah satu distro pada linux yang bersifat open source [7], sehingga penggunaan linux sangat banyak digunakan pada server[8] dan desktop, serta kelebihan linux kebal dengan virus yang banyak menyerang pada sistem operasi windows.

\section{METODE PENELITIAN}

tahapan metode penulis menggunakan empat tahapan adalah pertama Analysis mengambil kebutuhan yang akan dilaksanakan yaitu kebutuhan perangkat lunak dan kebutuhan perangkat keras[9], tahapan kedua desain akan membuat topologi[10] infrastruktur, tahapan ketiga implementation [11] dengan menerapkan setting dan konfigurasi pada dns server, tahap terakhir testing yaitu penulis melakukan monitoring pada dns server dan infrastruktur jaringan.

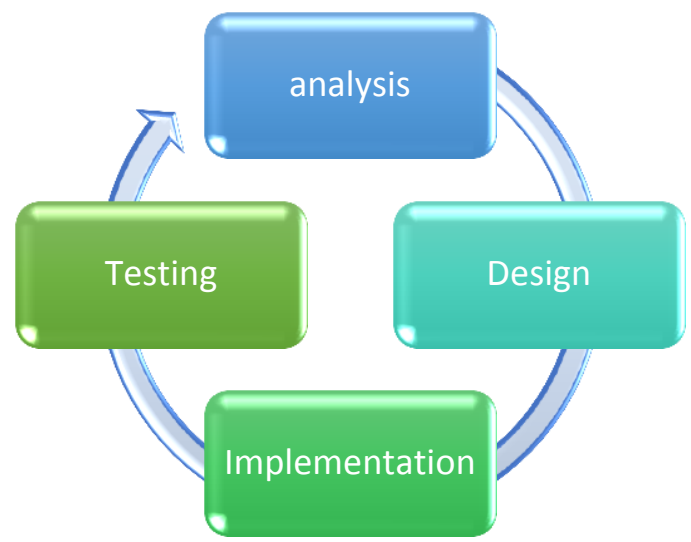

Gambar 1. Langkah - langkah Penelitian.

\section{Analysis}

Tahapan pertama penelitian yaitu analysis atau Analisa tentang Analisa kebutuhan yang dgunakan pada hardware dan software[12] dalam penelitian ini.
- Analysis kebutuhan perangkat keras terdiri dari PC/laptop yang digunakan sebagai domain name server lokal dengan spesifikasi prosesor core i3/i5 dan ram minimal 4GB dan ssd atau hardisk kosong sekitar 120GB. Dibutuhkan laptop/PC untuk user yang digunakan untuk tes akses dns server lokal. Spesifikasi untuk laptop/pc user 1, user 2 dan user 3 dapat menggunakan ram 2 gigabyte atau lebih, diutamakan menggunakan ram 4 GB agar hasil pengujian nanti bisa maksimal.

- Analysis kebutuhan perangkat lunak yang digunakan untuk dns server mengunakan sistem operasi linux ubuntu server 16.04. sedangkan untuk pengguna dapat menggunakan sistem operasi windows atau menggunakan linux ubuntu berbasis desktop.

\section{Design}

Tahapan kedua dalam penelitian ini yaitu design adalah penulis melakukan desain topologi jaringan yang akan digunakan dalam perancangan infrastruktur dns server lokal .

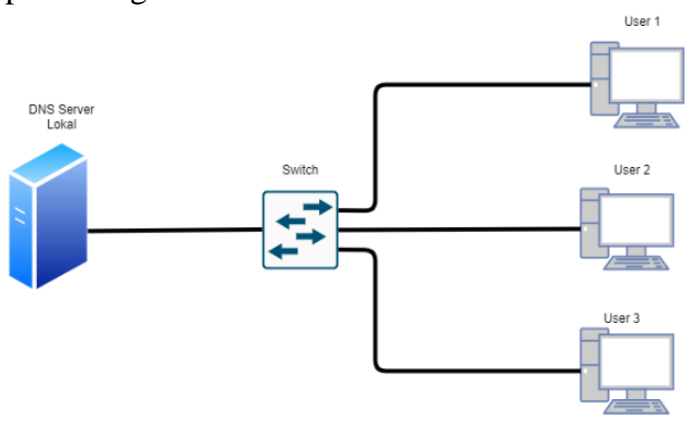

Gambar 2. Topologi Jaringan

Pada topologi jaringan diatas menggunakan satu jaringan dengan network $=200.200 .20 .0 / 24$ dengan asumsi dapat menampung user mencapai 254 pengguna. Server dengan ip address 200.200.20.2/24 dan user1 dengan ip address $=200.200 .20 .254 / 24$, user 2 dengan ip address $=200.200 .20 .253 / 24$, dan user 3 dengan ip address $=200.200 .20 .252 / 24$

\section{Implementation}




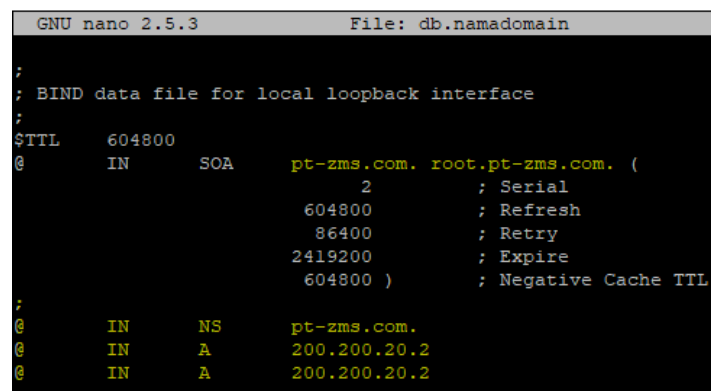

Gambar 7. File db.namadomain

Simpan file db.namadomain dengan cara ctrl x, ketik y dan enter.

- Konfigurasi file db.ipaddress

Pada konfigurasi file db.ipaddress dengan cara copy file db.127 kemudian paste dengan nama db.ipaddress, berikut perintahnya cp db.127 db.ipaddress, selanjutnya edit file db.ipaddress dengan menggunakan editor nano, dengan perintah nano db.ipaddress, dan edit konfigurasi sesuai dengan gambar dibawah ini.

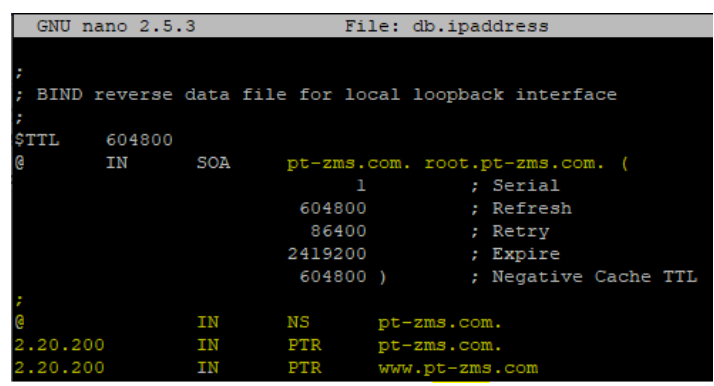

Gambar 8. Tampilan user engineering

Simpan file db.ipaddress dengan cara ctrl $\mathrm{x}$, ketik y dan enter

- Setting ip address static

Setting ip address static pada ubuntu server 16.04 dengan melakukan perintah nano /etc/network/interfaces, syaratnya harus sebagai root.

oot@ubuntu:/etc/bind\# nano/etc/network/interfaces

Gambar 9. Perintah setting ip address static

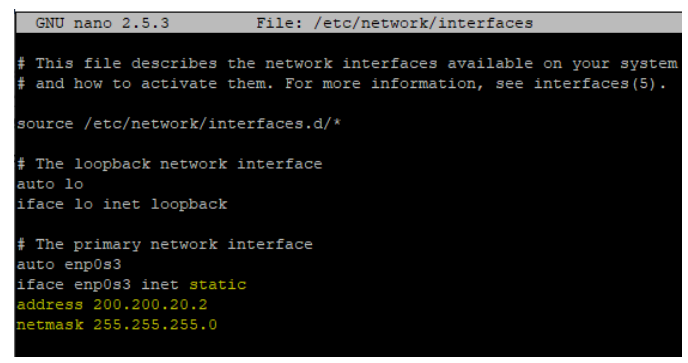

Gambar 10. Konfigurasi ip address static

Simpan konfigurasi dengan cara ctrl $\mathrm{x}$ kemudian tekan y dan enter. Setelah selesai disimpan restart service network dengan cara /etc/init.d/networking restart, lalu tunggu sampai hasil nya ok.

root lubuntu:/etc/bindł /etc/init.d/networking restart
[ ok ] Restarting networking (via systemct1): networking. service.

Gambar 11. Restart service network

Jika sudah direstart masih tidak berubah ip address nya, anda dapat reboot sistem operasi ubuntu server 16.04, setelah nyala kemudian cek ip address nya.

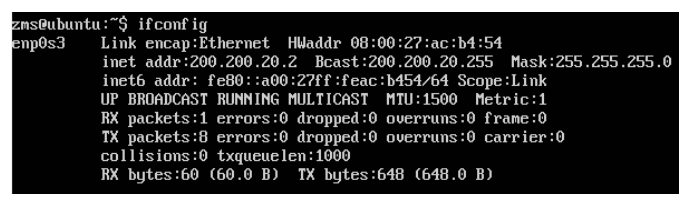

Gambar 12. Ip address server

- Setting ip address pada PC user 1

Setting ip address pada pc user 1 dengan menggunakan sistem operasi windows 10 , cara nya masuk ke control panel, kemudian pilih network and internet setting dan pilih network and sharing center kemudian pilih pada sebelah kanan change adapter setting.

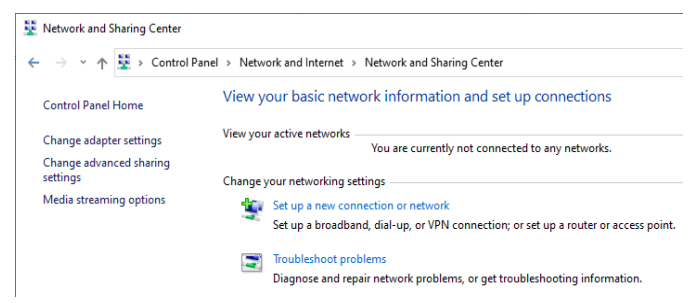

Gambar 13. Change adapter settings 
Klik dua kali pada ethernet dan pilih properties, kemudian pilih Internet Protocol Version 4 (TCP/IPv4) dan klik properties lagi, sehingga muncul tampilan seperti dibawah ini. Isi ip address subnet mask, dan preferred dns serta klik OK

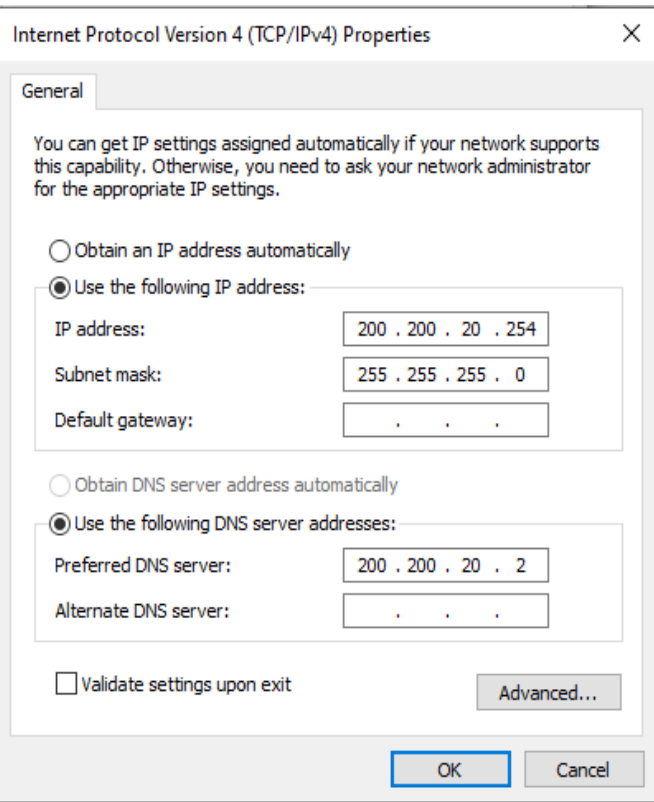

Gambar 14. Pengisian ip address

- Setting ip address pada user 2

Pada pc user 2 menggunakan sistem operasi windows 7, cara nya adalah klik pada control panel, kemudian klik network and internet, pilih network sharing and center, dan pilih change adapter settings

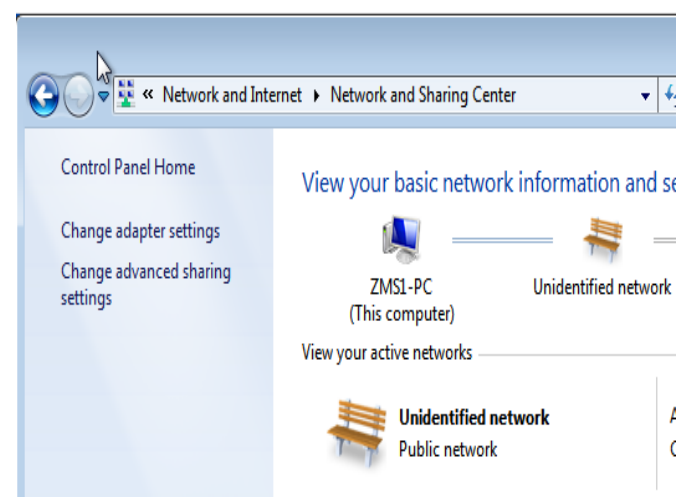

Gambar 15. Change adapter settings pada windows 7
Pada local area network klik dua kali sehingga akan muncul local area connection status dan klik properties dan pilih internet protocol version 4 (TCP/IPv4). Klik pada properties lagi, dan klik use the following ip address, isi ip address pada $\mathrm{PC}$ user 2 sesuai dengan tabel pengalamatan ip address dan klik OK.

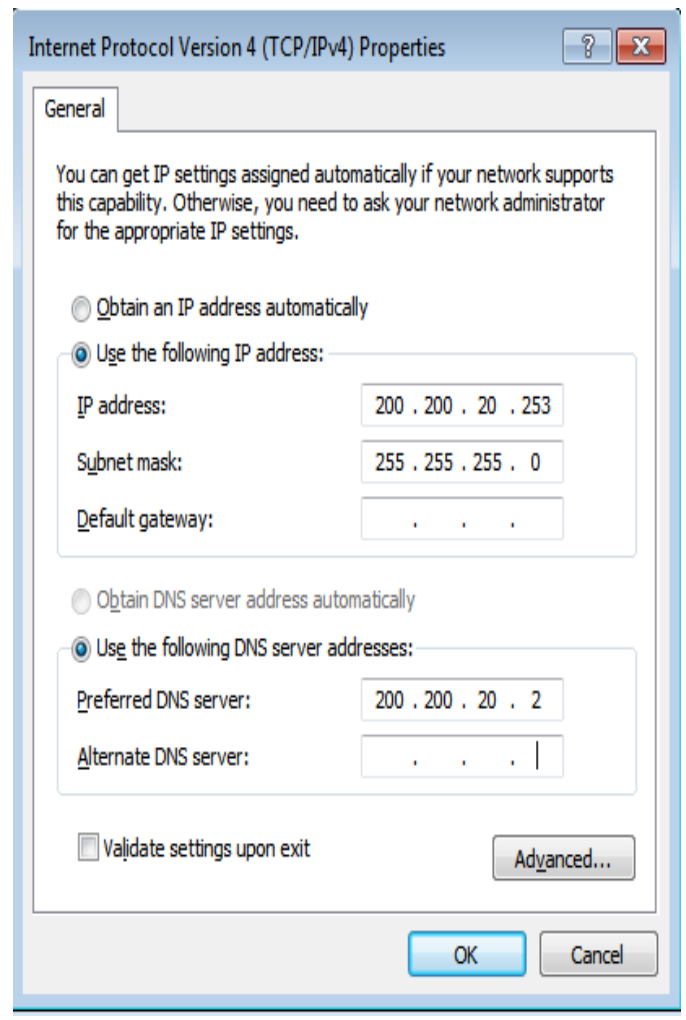

Gambar 16. Ip address pada pc user 2

Tes koneksi dari pc user2 ke server dengan menggunakan ping dan hasil nya adalah reply.

- Setting ip address pada user 3

Pada PC user 3 menggunakan sistem operasi windows 764 bit, untuk konfigurasi ip address nya sama dengan langkah pada setting ip address pada pc user 2, langsung saja dengan pengisian ip address pada pc user 3 . 


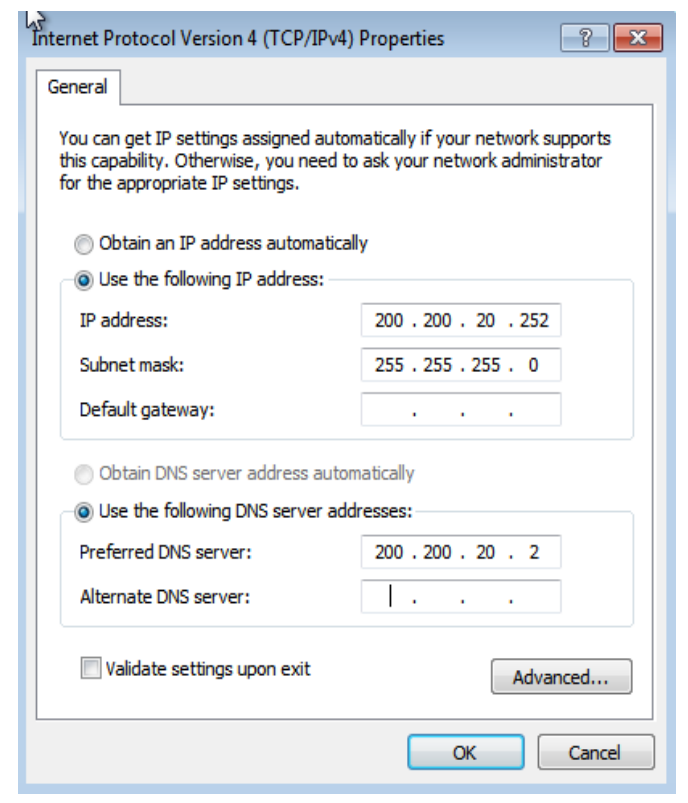

Gambar 17. Ip address pada pc user 3

- Pengujian

Pada pengujian pertama dengan menggunakan pengujian tes koneksi dari pc user ke pc server, dengan melakukan ping dari pc user ke dns server menggunakan alamat ip address.

Tabel 2. Tes koneksi menggunakan ip address

\begin{tabular}{|l|l|l|l|}
\hline No & Sumber & Tujuan & Hasil \\
\hline 1 & PC User 1 & 200.200 .20 .2 & Reply \\
\hline 2 & PC User 2 & 200.200 .20 .2 & Reply \\
\hline 3 & PC User 3 & 200.200 .20 .2 & Reply \\
\hline
\end{tabular}

Dari pengujian ketiga user mendapatkan pc user 1, 2 dan 3 dapat terkoneksi dengan server melalui ip address.

Pengujian kedua testing koneksi dari pc user ke nama domain, dengan melakukan ping dari pc user ke nama domain.

Tabel 3. Tes koneksi menggunakan nama domain

\begin{tabular}{|l|l|l|l|}
\hline No & Sumber & Tujuan & Hasil \\
\hline 1 & PC User 1 & $\begin{array}{l}\text { pt- } \\
\text { zms.com }\end{array}$ & Reply \\
\hline
\end{tabular}

\begin{tabular}{|l|l|l|l|}
\hline 2 & PC User 2 & $\begin{array}{l}\text { pt- } \\
\text { zms.com }\end{array}$ & Reply \\
\hline 3 & PC User 3 & $\begin{array}{l}\text { pt- } \\
\text { zms.com }\end{array}$ & Reply \\
\hline
\end{tabular}

Dari hasil pengujian pada tabel 3 menghasilkan bahwa semua pc user 1, 2 dan 3 dapat terkoneksi ke dns server pt-zms.com.

Pengujian ketiga dengan melakukan query ke domain dengan menggunakan perintah nslookup, berikut hasil nya

Tabel 4. Hasil query nslookup

\begin{tabular}{|c|c|c|c|c|}
\hline \multirow{2}{*}{$\begin{array}{l}\mathbf{N} \\
\mathbf{0}\end{array}$} & \multirow{2}{*}{$\begin{array}{l}\text { Sumb } \\
\text { er }\end{array}$} & \multirow{2}{*}{$\begin{array}{l}\text { Perint } \\
\text { ah }\end{array}$} & \multicolumn{2}{|l|}{ Hasil } \\
\hline & & & $\begin{array}{l}\text { Server/N } \\
\text { ame }\end{array}$ & Address \\
\hline 1 & $\begin{array}{l}\text { PC } \\
\text { User } \\
1\end{array}$ & $\begin{array}{l}\text { nslook } \\
\text { up pt- } \\
\text { zms.co } \\
\text { m }\end{array}$ & $\begin{array}{l}\text { pt- } \\
\text { zms.com }\end{array}$ & $\begin{array}{l}200.200 . \\
20.2\end{array}$ \\
\hline 2 & $\begin{array}{l}\text { PC } \\
\text { User } \\
2\end{array}$ & $\begin{array}{l}\text { nslook } \\
\text { up pt- } \\
\text { zms.co } \\
\text { m }\end{array}$ & $\begin{array}{l}\text { pt- } \\
\text { zms.com }\end{array}$ & $\begin{array}{l}200.200 . \\
20.2\end{array}$ \\
\hline 3 & $\begin{array}{l}\text { PC } \\
\text { User } \\
3\end{array}$ & $\begin{array}{l}\text { nslook } \\
\text { up pt- } \\
\text { zms.co } \\
\text { m }\end{array}$ & $\begin{array}{l}\text { pt- } \\
\text { zms.com }\end{array}$ & $\begin{array}{l}200.200 . \\
20.2\end{array}$ \\
\hline
\end{tabular}

Dari hasil pengujian pada tabel 4 yaitu hasil query ke nslookup ke pt-zms.com dari pc user 1 menghasilkan server/name pt-zms.com dan address 200.200.20.2, begitu juga hasil dari pc user 2 dan pc user 3 ..

\section{KESIMPULAN}

Domain name server lokal dapat diakomodasi dari sistem ubuntu server 16.04 dengan menginstall paket bind9 dan di tambah konfigurasi untuk menerjemahkan dari nama domain ke ip address dan menerjemahkan dari ip address ke nama domain, sehingga dari hasil pengujian pada tabel 3 tes koneksi menggunakan nama domain dapat terhubung, dan pada tabel 4 hasil pengujian cek query nslookup menghasilkan pengujian dari pc user 1, pc user 2, dan pc user 3 dapat menerjemahkan alamat domain pt-zms.com dengan ip address 200.200.20.2 


\section{DAFTAR PUSTAKA}

[1] Z. M. Subekti, "Implementasi Keamanan Akses Sharing Folder pada Windows 10," vol. 11, no. 1, 2021.

[2] A. Hafiz, T. Kurniawan, N. A. Sivi, F. K. Ikhsan, and P. Andhika, "Analisis Celah Keamanan Jaringan Dan Server Menggunakan Snort Intrusion Detection System," $J$. Inf. dan Komput., vol. 8, no. 2, pp. 59-66, 2020, doi: 10.35959/jik.v8i2.185.

[3] Z. M. Subekti, G. Rakasiwi, J. T. Komputer, J. T. Informatika, and J. T. Informatika, "Perancangan Infrastrruktur Web Server Dan Database Menggunakan Metode Replication Mirror Dan Failover," vol. XVIII, pp. 359-371, 2019.

[4] T. Hidayat, C. Iswayudi, and Suraya, "Optimalisasi Kinerja Server Menggunakanmanajemen Dns Optimizing Server Performance Using Dns Management (studi kasus : ist akprind yogyakarta)," Jarkom, vol. 5, no. 2, pp. 1-11, 2018.

[5] Z. M. Subekti and R. Kurniawan, "Perancangan Jaringan VoIP Berbasis Open Source Dengan DNS Pada Mikrotik," J. Cendikia, vol. 17, no. 4, pp. 242-245, 2019.

[6] A. Video, T. K. Ringan, and N. P. Ikan, "Rancang bangun dns server di smk negeri 3 tegal berbasis linux ubuntu," no. 09.
[7] D. Prabowo, A. Hidayat, and I. P. Saputra, "Implementasi Samba Server untuk Sharing Data Center pada Lab Komputer Universitas Muhammadiyah Metro," vol. 05, 2020.

[8] F. Nurrahman, "Implementasi Linux Ubuntu Server 18.04 Sebagai Server Sistem Informasi Akademik Pada Sekolah Tinggi Manajemen Informatika Dan Komputer Samarinda," J. DiJITAC, vol. 1, no. 1, pp. 55-77, 2020.

[9] Z. M. Subekti, "Rancang Bangun Wireless Access Point dengan Capsman dan Mac Mask Access list," vol. 04, no. 2, pp. 195-200, 2019, doi: 10.30591/jpit.v4i2-2.1878.

[10] Z. Mutaqin Subekti, “Optimasi Jaringan Wireless Lokal Area Network untuk Akses Finger Print," Syntax J. Inform., vol. 9, no. 2, pp. 6378, 2020, doi: 10.35706/syji.v9i2.4059.

[11] P. Limit, A. Browsing, I. Pada, S. Jam, K. Di, and P. T. Xyz, "Jurnal Teknologi Terpadu PENERAPAN LIMIT AKSES BROWSING INTERNET PADA SAAT JAM," vol. 7, no. 1, pp. 31-38, 2021.

[12] W. M. Wijaya and Z. M. Subekti, “Jurnal Manajemen Pendidikan Penerapan Aplikasi Database pada Kegiatan Manajemen Sekolah The Use of Database Applications in School Management Activities," vol. 1, no. 2, pp. 157-166, 2019. 